\title{
The effect of $\alpha$-terpineol on cell cycle, apoptosis and Bcl-2 family protein expression of breast cancer cell line MCF-7
}

\author{
Damiana Sapta Candrasari ${ }^{1 *}$, Sofia Mubarika², Mae Sri Hartati Wahyuningsih ${ }^{3}$ \\ ${ }^{1}$ Faculty of Pharmcy, Universitas Sanata Dharma, 2Department of Histology and Cell \\ Biology, ${ }^{3}$ Department of Pharmacology and Therapy, Faculty of Medicine, Universitas \\ Gadjah Mada, Yogyakarta, Indonesia.
}

DOI: http://dx.doi.org/10.19106/JMedSci004702201502

\begin{abstract}
The cytotoxic activity of $\alpha$-terpineol on T47D and HeLa cancer cell lines have been reported. This study was conducted to evaluate the effect of $\alpha$-terpineol on cell cycle, apoptosis and $\mathrm{Bcl}-2$ as well as Bax expression on MCF-7 cell line. The cytotoxic activity of $\alpha$-terpineol was determined using MTT cell assay. Cell cycle and apoptosis were analysed using flowcytometry, whereas $\mathrm{Bcl}-2$ and Bax expression were evaluated using immunohistochemistry. The results showed that $\alpha$-terpineol had cytotoxic effect on the MCF-7 cell lines with an $\mathrm{IC}_{50}$ value of $33.0 \pm 5.4 \mu \mathrm{g} / \mathrm{mL}$. $\alpha$-Terpineol induced cell accumulation in Sub-G1 lead to apoptosis of the MCF-7 cell. Moreover, $\alpha$-terpineol inhibited $\mathrm{Bcl}-2$ and induced Bax expressions. In conclusion, $\alpha$-terpineol has potential anticancer activity against MCF-7 cancer cell line trough through cells cycle inhibition and apoptosis stimulation.
\end{abstract}

\section{ABSTRAK}

Aktivitas sitotoksik $\alpha$-terpineol pada sel T47D dan HeLa telah dilaporkan sebelumnya. Penelitian ini dilakukan untuk mengkaji efek $\alpha$-terpineol terhadap siklus sel, apoptosis dan ekspresi Bcl-2 serta Bax pada sel MCF-7. Aktivitas sitotoksik $\alpha$-terpineol ditetapkan dengan metode MTT. Siklus sel dan apoptosis dianalisis dengan metode flowsitometri, sedangka ekspresi $\mathrm{Bcl}-2$ dan Bax ditetapkan dengan metode imunohistokimia. Hasil penelitian menunjukkan $\alpha$-terpineol mempunyai aktivitas sitotoksik dengn nilai $\mathrm{IC}_{50} 33,0$ $\pm 5,4 \mu \mathrm{g} / \mathrm{mL}$. $\alpha$-Terpineol menginduksi akumulasi sel MCF-7 pada fase Sub-G1 sehingga menyebabkan apoptosis. Lebih lanjut terbukti $\alpha$-terpineol menghambat ekspresi Bcl-2 dan menginduksi ekspresi Bax. Dapat disimpulkan, $\alpha$-terpineol mempunyai aktivitas antikanker pada sel MCF-7 melalui penghambatan pada siklus sel dan pacuan apoptosis.

Keywords: $\alpha$-terpineol - MCF-7 cell line - cytotoxicity - apoptosis - Bcl-2 - Bax 


\section{INTRODUCTION}

Breast cancer is the most frequently diagnosed cancer and the leading cause of cancer deaths in females worldwide, accounting for $23 \%$ (1.38 million) of the total new cancer cases and $14 \%(458,400)$ of the total cancer deaths in $2008 . .^{1-3}$ In Indonesia in 2008 , the incidence rate of breast cancer per 100,000 is 36.2 , while the mortality rate per 100,000 is $18.6 .{ }^{4}$ In the 2007 data obtained from Dharmais Hospital, National Cancer Center, Jakarta, it was reported that 437 breast cancer patients had been hospitalized among a total of 1,264 out patients. ${ }^{5}$

Chemotherapy is a treatment option for most types breast cancer. It is normally performed in conjunction with surgery and radiotherapy. ${ }^{6}$ However, chemotherapy owns disadvantages ranging from adverse effects of drugs to patients' death. ${ }^{7}$ In addition, resistance to anticancer remains a major problem in chemotherapy. ${ }^{8}$ Face the problems in this chemotherapy, efforts to find a new anticancer that more sensitive and specific is urgently needed. Medicinal plant has been a source of new anticancer agents during last few decades. Many anticancers used in clinic have been developed from medicinal plants like vincristine, camptothecin, and docetaxel. ${ }^{9}$

$\alpha$-Terpineol is, a monoterpenooid alcohol, one of natural agents that has potential anticancer activity. $\alpha$-Terpineol is the major components of terpineol that has been isolated from a variety of plants such as Eucalyptus globulus (Eucalyptus) and Pinus merkusii (Pinus). ${ }^{10,11} \alpha$-Terpineol is usually present in a mixture of three isomers namely $\beta$-, $\gamma$ - and terpinen-4-ol. ${ }^{12}$ The potency of $\alpha$-terpineol as anticancer candidate has been reported by some authors. $\alpha$-Terpineol has been proven to be able to induce cell cycle and apoptosis of colon cancer HCT-116 cells in vitro through caspase activation, cytochrome $\mathrm{C}$ release and PARP cleavage. ${ }^{13}$ Whereas, Hassan et al. ${ }^{14}$ proved that $\alpha$-terpineol is able to prevent the MCF-7 and HeLa cells growth by supressing NF-kB signalling pathway.

In order to develop $\alpha$-terpineol as a potential anticancer, Budiman et al. ${ }^{11}$ synthesized $\alpha$-terpineol from $\alpha$-pinene isolated from Indonesian crude turpentine. Furthermore, this $\alpha$-terpineol synthesized has been proven its cytotoxicity on T47D and HeLa cancer cell lines by induce the cell apoptosis and inhibit cell cycle. ${ }^{15,16}$ In this study we continued to investigate the cytotoxicity of $\alpha$-terpineol on MCF-7 and its effect on cell cycle, apoptosis and $\mathrm{Bcl}-2$ as well as Bax proteins expression.

\section{MATERIALS AND METHODS}

\section{Materials}

$\alpha$-Terpineol was synthesized by Prof Arief Budiman from Department of Chemical Engineering, Faculty of Engineering, Universitas Gadjah Mada, Yogyakarta. MCF7 cell line was kindly provided by Stem Cell and Cancer Institute Kalbe Farma, Jakarta.

\section{Cell cultures}

MCF-7 cells line were culture in tissue culture flask $25 \mathrm{~cm}^{2}$ containing DMEM high glucose, insulin, 10\% FBS, 2\% penisilinstreptomisin, and $0.5 \%$ fungizone. Cultures were maintained in $5 \% \mathrm{CO}_{2}$ incubator at $37^{\circ} \mathrm{C}$. After 24 hours, medium was replaced and cells were grown until 70\% - 80\% confluency for further experiments.

\section{Cytotoxicity assay}

Cytotoxicity of $\alpha$-terpineol was evaluated on MCF-7 cells using the MTT assay as reported by Mosmann after modification. ${ }^{17}$ Cells were distributed in 96-wells microplates at $2 \times 10^{4}$ cells per well in $100 \mathrm{~mL}$ and 100 
$\mathrm{mL}$ of complete DMEM medium were added. The cell cultures were then incubated in 5\% $\mathrm{CO}_{2}$ incubator at $37^{\circ} \mathrm{C}$ for 24 hours. After incubation, the medium was removed and replaced with new complete DMEM medium with various concentrations of $\alpha$-terpineol. Cells culture and $\alpha$-terpineol were incubated again in $5 \% \mathrm{CO}_{2}$ incubator at $37^{\circ} \mathrm{C}$ for 24 hours. After the incubation, the medium was removed and the cells were resuspended in DMEM medium, $10 \mu \mathrm{L}$ of $5 \mathrm{mg} / \mathrm{mL}$ MTT [3-9,4,5-dimethylthiazole-2-yl2,5diphenyltetrazolium bromide] and then further incubated for 4 hours. The reaction was stopped by adding $100 \mu \mathrm{L}$ of $10 \%$ sodium dodecyl sulfate (SDS) in $0.01 \mathrm{~N} \mathrm{HCl}$. Microplate was then shaken gently for 5 minutes, covered with aluminium foil and incubated at room temperature overnight. Absorbance of the microplate was measured in an ELISA plate reader at $\lambda_{\text {max }} 595 \mathrm{~nm}$. The absorbance values were directly proportional to the number of live cells. The absorbance values in the presence of $\alpha$-terpineol were compared with that of control cultures without $\alpha$-terpeniol to obtain cells growth inhibition. For this MTT method, $\mathrm{IC}_{50}$ (inhibitory concentration of $50 \%$ cell growth) values were determined by probit analysis based on the relationship between log concentrations versus the percentage of cells growth inhibition.

\section{Cell cycle analysis}

Cells cycle analysis was performed by flowcytometry. MCF-7 cell line were seeded in 6-well plates at $5 \times 10^{5}$ cells/well and incubated 24 hours, $37^{\circ} \mathrm{C}, 5 \% \mathrm{CO}_{2}$. After 24 hours, cells were treated with $\alpha$-terpineol in triplicate at 2 concentrations: $1 / 2 \mathrm{IC}_{50}$ and $\mathrm{IC}_{50}$ for 24 hour. At the end of the incubation period, cells were collected and harvested. After centrifugation, cell pellets were washed twice with $500 \mu \mathrm{L}$ of cold PBS and then added $1 \mathrm{~mL}$ of $70 \%$ ice-cold ethanol and stored at $-20^{\circ} \mathrm{C}$ for 30 minutes. The fixed cell centrifugated, the pellet was washed once with PBS and then incubated with Propidium Iodide reagen for 10 minutes in $37^{\circ} \mathrm{C}$ and transferred to flowcytotube. The cells were immediately analyzed by FACS Calibur flowcytometer to evaluate cell cycle profile. Flowcytometric data were analysed using Cell Quest to evaluate the cells distribution at each phase of the cell cycle namely the sub G1 (apoptosis), $\mathrm{S}, \mathrm{G} 2 / \mathrm{M}$, and the cells undergoing polyploidy. The cell cycle inhibition was observed by comparing the cells distribution at G0/G1 and G2/M phases of treated and untreated cells. Ethical approval of the study was obtained the Medical and Health Research Ethics Committee, Faculty of Medicine, Universitas Gadjah Mada, Yogyakarta.

\section{Apoptosis}

Cells cycle analysis was performed by flowcytrometry. MCF-7 cell line were suspended at a final concentration of $5 \mathrm{x}$ $10^{5}$ cells/well in complete DMEM medium and distributed in 24 wells. The cells were then incubated for 24 hours, at $37^{\circ} \mathrm{C}$ in $5 \%$ $\mathrm{CO}_{2}$. After 24 hours of incubation, cells were treated with $\alpha$-terpineol in triplicate at 2 concentrations: $1 / 2 \mathrm{IC}_{50}$ and $\mathrm{IC}_{50}$ for 24 hour. At the end of the incubation period, cells were collected, washed twice with $500 \mu \mathrm{L}$ PBS, and then incubated with Annexin V FluosPropidium Iodide reagent for 10 minutes. The result of the staining was then detected using FACS Calibur.

\section{Immunohistochemical analysis of Bcl-2 and Bax proteins expression}

Bcl-2 and Bax proteins expression was performed by immunohistochemistry. MCF7 cell line were distributed in 24-well plates at $75 \times 10^{3}$ cells/well and incubated at $37^{\circ} \mathrm{C}$ 
in $5 \% \mathrm{CO}_{2}$ for 24 hours. Followed after incubation, cells were treated with $\alpha$-terpineol in triplicate at 2 concentrations: $1 / 2 \mathrm{IC}_{50}$ and $\mathrm{IC}_{50}$ for 24 hour. At the end of incubation period, cells were washed twice with PBS. The cells were incubated at $4^{\circ} \mathrm{C}$ for one hour with dilution of primary antibodies against Bcl-2 (dilution 1:400) or Bax (dilution 1:400) and then were washed with PBS three times. The cells were subsequently incubated with biotinylated secondary antibodies for five minutes, washed with PBS and incubated with HRP-conjugated streptavidin. The cells were washed with PBS and then visualized using 3,3'-diaminobenzidine (DAB) chromogen and counterstained with Harry's haematoxylin. The cells were washed with PBS, dried, mounted in Canada balsam, and observed at $400 \mathrm{x}$ magnification using an image analysis system.

\section{Statistical analysis}

Data were expressed as the mean \pm standard deviation (SD). Statistical comparisons were performed using Student'st-test. A $\mathrm{p}$ value less than 0.05 was considered to indicate statistically significant.

\section{RESULTS}

\section{Cytotoxicity of $\alpha$-terpineol on MCF-7 cell line}

The inhibition of MCF-7 cells growth after incubation with $\alpha$-terpineol in various different concentrations for 24 hours is presented in TABLE 1. A dose-dependent manner in MCF-7 cells growth after incubation with $\alpha$-terpineol was observed. The maximum growth inhibition (100\%) was observed after incubation with $\alpha$-terpineol in concentration of $200 \mu \mathrm{g} / \mathrm{mL}$. Probit analysis showed that the $\mathrm{IC}_{50}$ value of $\alpha$-terpineol on MCF-7 cell line was $33.0 \pm 5.4 \mu \mathrm{g} / \mathrm{mL}$.

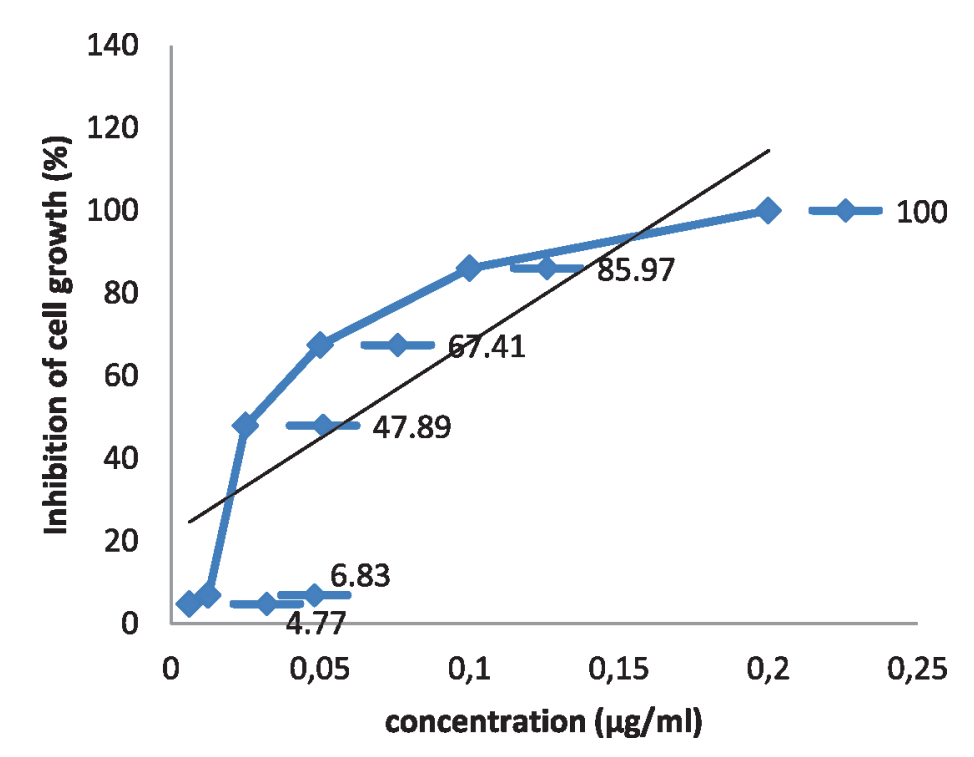

FIGURE 1. Growth inhibition of MCF-7 cells $(\% \pm$ SD) after 24 hours incubation with the $\alpha$-terpineol 
The effect of $\alpha$-terpineol on MCF-7 cell cycle

The effect of $\alpha$-terpineol on the MCF-7 cell cycle changes was enalyzed by flowcytometry. FIGURE 2 shows the MCF-7 cell cycle profile after incubation with $\alpha$-terpineol at 2 different concentrations (16.5 and $33.0 \mu \mathrm{g} / \mathrm{mL})$. $\alpha$-Terpineol at concentration of $33.0 \mu \mathrm{g} / \mathrm{mL}$ $\left(\mathrm{IC}_{50}\right)$ induced MCF-7 cell accumulation until $18.59 \%$ at Sub-G1 phase. This accumulation was accompanied with the reduction of cycling cells in G0/G1 phase $(51.24 \%)$, S phase $(15.4 \%)$ and G2M phase $(9.69 \%)$ as compared to control. At concentration of 16.5 $\mu \mathrm{g} / \mathrm{mL}\left(1 / 2 \mathrm{IC}_{50}\right), \alpha$-terpineol induced MCF-7 cell accumulation until $24.78 \%$ at $\mathrm{S}$ phase, as compared to $21.15 \%$ in the control cells. The cell accumulation in $\mathrm{S}$ phase caused reduction of cycling cells in G2M phase.

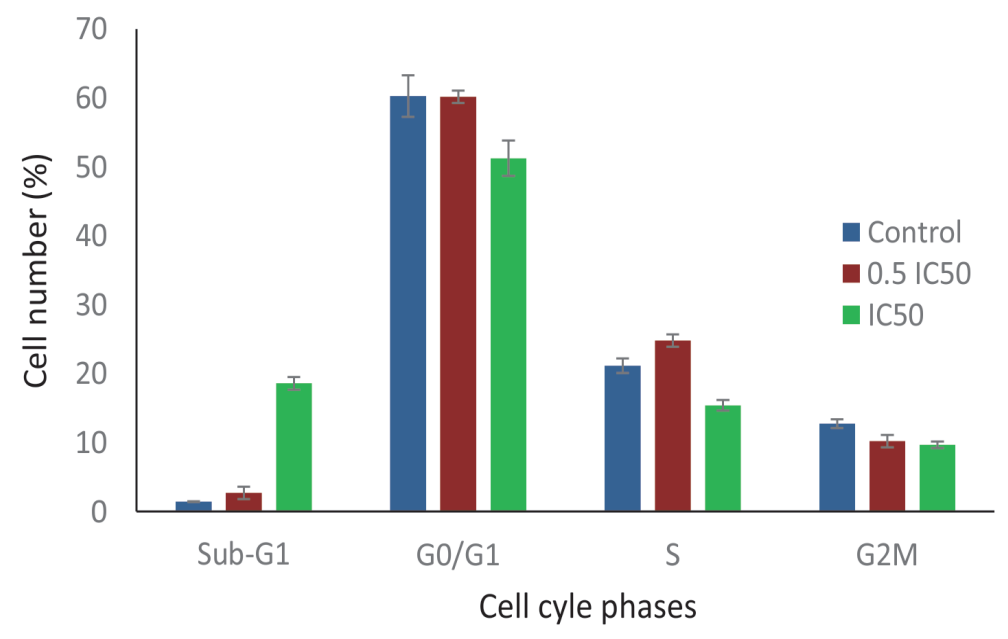

FIGURE 2. Cell cycle analysis of MCF-7 cell line using flowcytometri afer 24 hours incubation with $\alpha$-terpineol compared to control

\section{The effect of $\alpha$-terpineol on apoptosis}

The effect of $\alpha$-terpineol on the MCF-7 cell apoptosis was analysed by flowcytometry using Annexin V Fluos-Propidium Iodide staining. TABLE 1 shows MCF-7 cell distribution in four quadrant, whereas its percentage of early apoptotic cell after 24 hours $\alpha$-terpineol incubation compared to control is presented in FIGURE 2. The percentage of apoptotic cell after 24 hours incubation with $\alpha$-terpineol at concentration of $33.0 \mu \mathrm{g} /$ $\mathrm{mL}(5.92 \pm 0.13 \%)$ was significantly higher than that at concentration $16.5 \mu \mathrm{g} / \mathrm{mL}(2.57$ $\pm 0.12 \%)$ and that control $(1.03 \pm 0.06 \%)(\mathrm{p}$ $<0.05)$.

TABLE 1. MCF-7 cell distribution in four quadrant (lower left/live, lower right/ early apoptotic cell, upper right/ necrotic cell, upper left/necrotic cell)

\begin{tabular}{lccccc}
\hline \multirow{2}{*}{ Treatment } & \multirow{2}{*}{ Concentration $(\mu \mathrm{g} / \mathrm{mL}$} & \multicolumn{4}{c}{ Cell percentage $(\% \pm \mathrm{SD})$} \\
\cline { 3 - 6 } & & Live & Early apoptotic & Necrotic & Necrotic \\
\hline Control & 0 & $96.42 \pm 0.43$ & $1.03 \pm 0.06$ & $0.59 \pm 0.08$ & $1.95 \pm 0.33$ \\
Alpha terpineol & 16.5 & $87.48 \pm 0.05$ & $2.57 \pm 0.12$ & $0.53 \pm 0.03$ & $9.42 \pm 0.15$ \\
& 33.0 & $86.45 \pm 0.37$ & $5.92 \pm 0.13$ & $1.07 \pm 0.07$ & $6.44 \pm 0.19$ \\
\hline
\end{tabular}




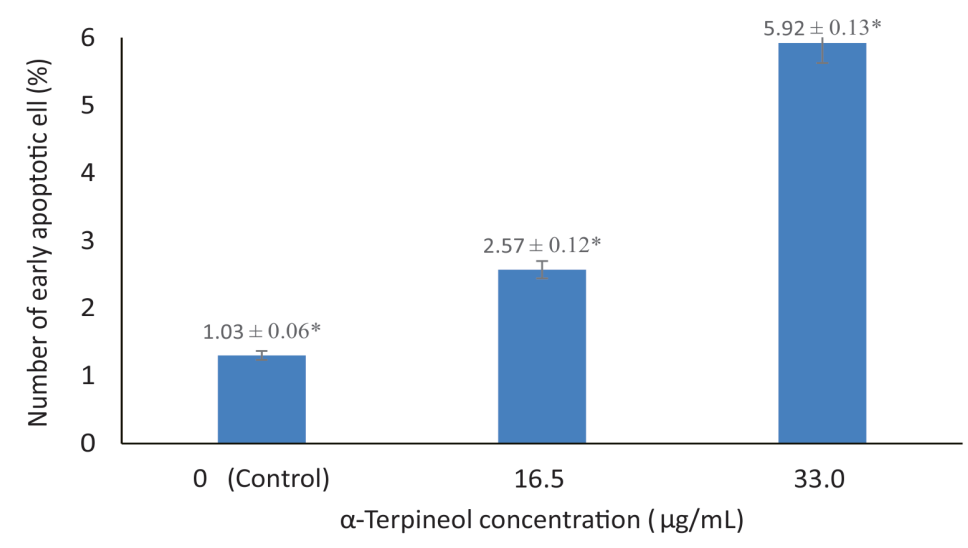

FIGURE 3. The effect of 24 hours $\alpha$-terpineol incubation on apoptosis stimulation on MCF-7 cell line. *significantly different $(\mathrm{p}<0.05)$

The effect of $\alpha$-terpineol on Bcl-2 and Bax expressions

The effect of $\alpha$-terpineol on Bcl-2 and Bax expressions of the MCF-7 cell were analysed by immunohistochemistry. The expression of Bcl-2 and Bax protein on MCF-7 cell line after 24 hours $\alpha$-terpineol incubation are presented in FIGURE 4 and 5, respectively. The percentage of Bcl-2 expression after 24 hours incubation with $\alpha$-terpineol at concentration of 16.5 and $33.0 \mu \mathrm{g} / \mathrm{mL}$ (59.8 and 56.2\%) were lower than that control (95.8\%). Inversely, the percentage of Bax expression after 24 hours incubation with $\alpha$-terpineol at concentration of $33.0 \mu \mathrm{g} / \mathrm{mL}(100 \%)$ was significantly higher than that at concentration $16.5 \mu \mathrm{g} / \mathrm{mL}$ $(68.0 \%)$ and that control (53.2).

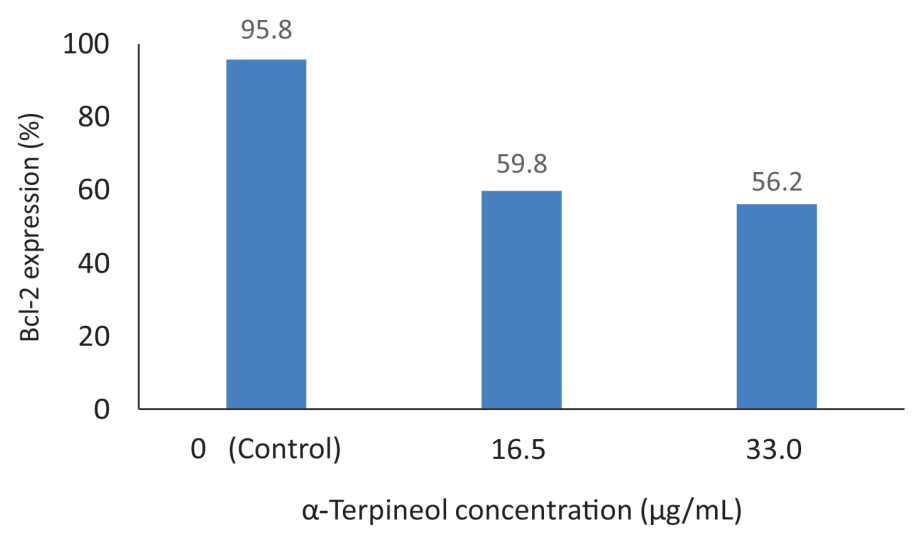

FIGURE 4. The effect of 24 hours $\alpha$-terpineol incubation on Bcl-2 expression of $\mathrm{MCF}-7$ cell line 


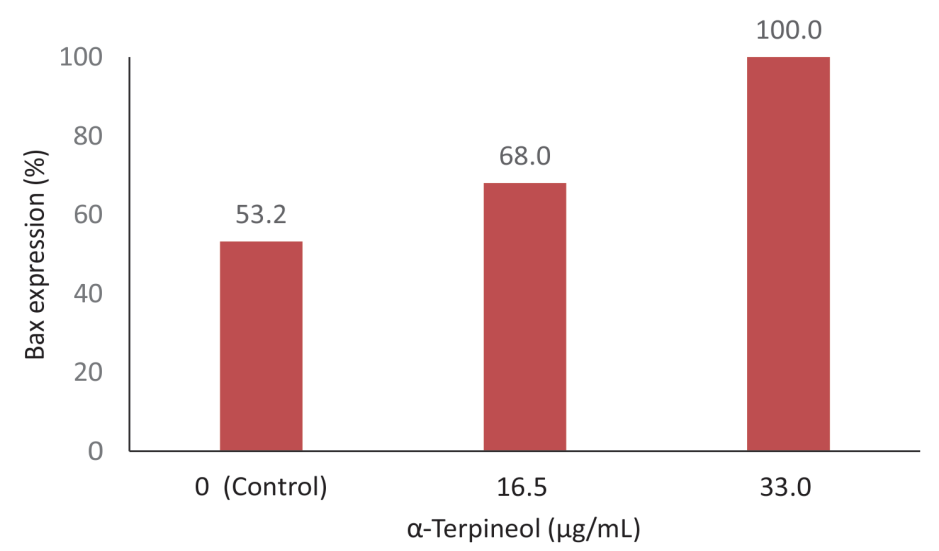

FIGURE 5. The effect of 24 hours $\alpha$-terpineol incubation on Bax expression of $\mathrm{MCF}-7$ cell line

\section{DISCUSSION}

This study showed that $\alpha$-terpineol inhibited the MCF-7 cell growth in a dosedependent manner with an $\mathrm{IC}_{50}$ value of 33.0 $\mu \mathrm{g} / \mathrm{mL}$. The cytotoxicity of $\alpha$-terpineol on different cancer cell lines has been reported in the previous studies by some authors. Hasan et $a l .{ }^{14}$ reported that $\alpha$-terpineol was most active on NCI-H69 lung cancer cell with $\mathrm{IC}_{50}$ of $39.4 \mu \mathrm{g} / \mathrm{mL}$ among 14 human cancer cell lines tested. $\alpha$-Terpineol was also reported active against T47D breast cancer cell line $\left(\mathrm{IC}_{50}: 20.5 \mu \mathrm{g} / \mathrm{mL}\right)^{15}$ and HeLa cervical cancer cell line $\left(\mathrm{IC}_{50}: 12.5 \mu \mathrm{g} / \mathrm{mL}\right) .{ }^{16}$ Based on a criteria proposed by America National Cancer Institute, $\alpha$-terpineol can be classified as a potential anticancer agent $\left(\mathrm{IC}_{50}\right.$ about $30 \mu \mathrm{g} /$ $\mathrm{mL}){ }^{18}$

The effect $\alpha$-terpineol on MCF-7 cell cycle in this study showed that $\alpha$-terpineol induced cell cycle arrest in the cell line tested in a dose-dependent manner. This result is consistent with the previous reports which showed that $\alpha$-terpineol is active in inducing cell cycle arrest. Itani et al..$^{13}$ reported that Salvia libanotica essential oil containing three bioactive compounds i.e. linalyl acetate, terpeniol and camphor caused significant growth suppression of colorectal cancer cell lines HCT116 (p53 $\left.3^{+/+}\right)$in pre G1 phase and in $\mathrm{p} 53^{-/}$cells caused cell accumulation in pre G1 and G2/M phases. Moreover, Hassan et al. ${ }^{14}$ also reported that $\alpha$-terpineol inhibited the proliferation of lymphoma U937-GTB cancer cells in $\mathrm{G} 0 / \mathrm{G} 1$ phase lead to reduction in the number of cells in the later stages of cell cycle (S, G2 and M) of the cells.

This study also showed that $\alpha$-terpineol induced apoptosis of the cell line tested in a dose-dependent manner. The apoptosis induced by $\alpha$-terpineol may be through Bcl-2 protein family as demonstrated by the decrease of Bcl-2 ad the increase of Bax expressions in this study. The effect of $\alpha$-terpineol on cancer cell apoptosis has been demonstrated previously. Itani et al. ${ }^{13}$ reported that $\alpha$-terpineol, linaly acetate and camphor synergised to induce cell cycle arrest and apoptosis, mainly via mitochondrial damage (cytochrome crelease), caspase activation, and PARP cleavage, in human colorectal cancer cells. Furthermore, Hassan et al. ${ }^{14}$ reported that $\alpha$-terpineol exhibited a potential anticancer which acts by suppressing NF- $\kappa \mathrm{B}$ which signals various cancer cells line. NF$\kappa \mathrm{B}$ protein is one of transcription factors that 
are involved in the control of inflammatory responses, developmental processes, cellular growth and apoptosis. ${ }^{18} \alpha$-Terpineol inhibits $\mathrm{NF}-\kappa \mathrm{B}$ translocation and activity and downregulates the expression of several NF$\kappa B$-related genes such as IL- $1 \beta$ and IL1R1 resulting in the inhibition of cancer cells growth. ${ }^{14}$

\section{CONCLUSION}

In conclusion, $\alpha$-terpineol has potential anticancer activity against MCF-7 cancer cell line trough through cells cycle inhibition and apoptosis stimulation. The cells cycle inhibition is indicated by the induction of cell accumulation in Sub-G1, whereas cells apoptosis induction may be through $\mathrm{Bcl}-2$ protein family as demonstrated by the decrease of Bcl-2 ad the increase of Bax expressions.

\section{ACKNOWLEDGMENTS}

We would like to thank Prof. Ir. Arief Budiman, MS, D.Eng. who kindly provided $\alpha$-terpineol. We also would like to Stem Cell and Cancer Institute, Kalbe Farma, Jakarta who provided MCF-7 cell line. This study was funded by Ministry of Health, Republic of Indonesia through Iptekdok Risbin Research Grand 2011.

\section{REFERENCES}

1. Ferlay J, Shin HR, Bray F, Forman D, Mathers C, Parkin DM. Estimates of worldwide burden of cancer in 2008: GLOBOCAN 2008. Int J Cancer 2010 ; 127(12):2893-917. http:// dx.doi.org/10.1002/ijc.25516

2. Bray F, Ren JS, Masuyer E, Ferlay J. Global estimates of cancer prevalence for 27 sites in the adult population in 2008. Int $\mathrm{J}$
Cancer 2012; 132(5):1133-45. http://dx.doi. org/10.1002/ijc.27711

3. Jemal A, Bray F, Center MM, Ferlay J, Ward E, Forman D. Global cancer statistics. Ca Cancer J Clin 2011;61:69-90. http://dx.doi. org/10.3322/caac.20107

4. Kimman M, Norman R, Jan S, Kingston $\mathrm{D}$, Woodward M. The burden of cancer in member countries of the Association of Southeast Asian Nations (ASEAN). Asian Pacific J Cancer Prev13; 411-20. http:// dx.doi.org/10.7314/APJCP.2012.13.2.411

5. Bidang Rekam Medis RSKD. 10 besar kanker tersering di RS Kanker Dharmais rawat jalan (kasus baru) tahun 2007 [serial online].2009 [cited 2015 January 22]. Available from URL: http://www.dharmais.co.id/index.php/ statistic-center.html

6. Michaud LB, Espirito JL, Esteva FJ. Breastcancer. In: Dipiro JT, Talbert RT, Yee GC, Matzke GR, Wells BG, Posey LM, Eds. Pharmacotherapy: a pathophysiologic approach, 7th ed., NewYork:The McGrawHill Companies, Inc., 2008: 2121-56.

7. Medina PJ, Fausel C. Oncologic disorders, cancer treatment and chemotherapy. In: DipiroJT, Talbert RT, Yee GC, Matzke GR, Wells BG, Posey LM, Eds. Pharmacotherapy: a pathophysiologic approach, 7th ed., New York: The McGraw-Hill Companies, Inc., 2008: 2099.

8. Partridge AH, Burstein HJ, Winer EP. Side effects of chemotherapy and combined chemohormonal therapy in women with early-stage breast cancer. J Natl Cancer Inst Monogr 2001;30:135-42. http://dx.doi.org/10.1093/oxfordjournals. jncimonographs.a003451

9. Cragg GM, Grothaus PG, Newman DJ. Impact of natural products on developing new anticancer agents. Chem Rev 2009; 109: 3012-43. http://dx.doi.org/10.1021/cr900019j 
10. Moreira MR, Cruz GMP, Lopes MS, Albuquerque AAC, Leal-Cardoso JH. Effects of terpineol on the compound action potential of the rat sciatic nerve. Braz J Med Biol Re 2001; 34: 1337-40. http://dx.doi.org/10.1590/ S0100-879X2001001000015

11. Budiman A, Arifta TI, Dina, Sutijan. Continuous production of $\alpha$-terpineol from $\alpha$-pinene isolated from Indonesian crude turpentine. Modern Appl Sci 2015; 9(4): 22532. http://dx.doi.org/10.5539/mas.v9n4p225 MSDS. 2009. Terpineol. [serial online] 2009 [cited, 2015 January 25th] Available from: http:// www.sciencelab.com/msds. php?msdsId $=9925180$

12. Itani WS, El-Banna SH, Hassan SB, Larsson RL, Bazarbachi A, Gali-Muhtasib HU. Anticolon cancer components from lebanese sage (Salvia libanotica) essential oil. Cancer Biol Ther 2008; 7(11):1765-73. http://dx.doi. org/10.4161/cbt.7.11.6740

13. Hassan SB, Galib-Muhtasib H, Goransson H, Larsson R. Alpha terpineol: a potential anticancer agent which acts through suppressing NF- $\mathrm{KB}$ signalling. Anticancer Res 2010; 30:1911-20.

14. Indrasetiawan $P$, Astuti I, Mustofa. Activity of $\alpha$-terpineol as a potential anticancercandidate:cytotoxicity, pro apoptotican dan tiproliferative evaluation in TD47 cell lines. J Med Sci 2012; 44(1):10-7.

15. Rasuane N, Astuti I, Mustofa. Cytotoxicity of $\alpha$-terpineol in HeLa cell line and its effects to apoptosis and cell cycle. J Med Sci 2014; 46(1):1-9.

16. Mossman T. Rapid colorimetric assay for cellular growth and survival: application to proliferation and cytotoxicity assays. J Immunol Methods 1983; 65(1-2):55-63. http:// dx.doi.org/10.1016/0022-1759(83)90303-4

17. Suffness M, Pezzuto JM. Assays related to cancer drug discovery. In: Hostettmann K editor. Methods in plant biochemistry: assays for bioactivity, vol. 6. London: Academic Press, London, 1990: 71-133.

18. Gilmore T. NF-kB transcription factors [serial on line] 2011 [cited 2011, October 31st] Available on: http://www.bu.edu/nf-kb/ 